\title{
Identification of Aroma Compounds in Freeze-dried Strawberries and Raspberries by HS-SPME-GC-MS
}

\author{
Fadwa Al-Taher ${ }^{1} \&$ Boris Nemzer ${ }^{1,2}$ \\ ${ }^{1}$ VDF FutureCeuticals, Inc, Momence, IL 60954, USA \\ ${ }^{2}$ University of Illinois at Urbana-Champaign, Urbana, IL 61801, USA \\ Correspondence: Fadwa Al-Taher, VDF FutureCeuticals, 2692 N. State Rt. 1-17, Momence, IL 60954, USA. Tel: \\ 1-815-507-1421. E-mail: Fadwa.Al-Taher@futureceuticals.com
}

Received: May 12, 2020

doi:10.5539/jfr.v9n4p30

\author{
Accepted: June 19, 2020 \\ Online Published: July 4, 2020 \\ URL: https://doi.org/10.5539/jfr.v9n4p30
}

\begin{abstract}
The objective of this study was to determine a method for the identification of aroma volatile compounds in freeze-dried (FD) strawberries and raspberries for quality purposes. The aroma profile was examined using headspace solid-phase micro-extraction (HS-SPME) coupled with gas chromatography-mass spectrometry (GC-MS). FD strawberries and raspberries were extracted at four different times (10,15, 20 and $30 \mathrm{~min})$ and three different temperatures $\left(40{ }^{\circ} \mathrm{C}, 60{ }^{\circ} \mathrm{C}\right.$ and $\left.80{ }^{\circ} \mathrm{C}\right)$ using a SPME fiber coated with 50/30 $\mu \mathrm{m}$ divinylbenzene/carboxen on polydimethylsiloxane (DVB/CAR-PDMS) to determine optimum recoveries for aroma volatile compounds. The DVB/CAR-PDMS SPME fiber showed the best extraction of aroma volatile compounds from strawberry and raspberry at $60^{\circ} \mathrm{C}$ for $15 \mathrm{~min}$. Twenty-nine volatile compounds were identified from the strawberry samples and 20 from the raspberry samples, including terpenes, aldehydes, esters, acids and alcohols. Select aroma compounds in FD strawberries and raspberries were quantitated using SPME and GC-MS. It is important to determine the desirable aroma active compounds in freeze-dried strawberries and raspberries for quality uses since they are becoming popular commercially.
\end{abstract}

Keywords: aroma compounds, GC-MS, HS-SPME, strawberry, raspberry

\section{Introduction}

Aroma is an important characteristic of fruit quality that is gaining increased attention. Aroma volatile compounds are specific to the genus and to the variety of the fruit. Although some fruits may have similar aroma compounds, each fruit has a unique aroma that depends upon the combination of the volatiles and their concentration. These volatile compounds may play a key role in determining the acceptability of products by consumers (Hadi, Zhang, Wu, Zhou \& Tao, 2013)

Fresh strawberry (Fragaria $x$ ananassa) is one of the most complex fruits containing an estimated 350 volatile aroma compounds. The two major dominating aroma compounds are the furanones, 2,5-dimethyl-4-hydroxy-3(2H)-furanone (furaneol) and 2,5-dimethyl-4-methoxy-3(2H)-furanone (mesifurane) (Hadi et al., 2013; Jetti, Yang, Kunianta, Funn \& Qian, 2007; Jouquand \& Chandler, 2008; Forney, 2001). These give strawberry the sweet, flowery scent. Esters are significant comprising $25 \%$ to $90 \%$ of the total number of volatiles in ripe strawberry fruit with the important ones being methyl and ethyl butanoate, butyl acetate, and methyl and ethyl hexanoate (Hadi et al., 2013; Jetti et al., 2007; Jouquand \& Chandler, 2008; Forney, 2001). Some other important aroma compounds are linalool, $\gamma$-decalactone and 2,3-butanedione, but these are specific to the cultivar and promote the pleasant coconut and citrus odor (Hadi et al., 2013; Jetti et al., 2007; Jouquand \& Chandler, 2008). Some aldehydes and alcohols also are important and contribute to the green, unripened strawberries (Jetti et al., 2007; Jouquand \& Chandler, 2008; Forney, 2001).

Approximately 300 volatile compounds have been found in fresh raspberry (Rubus idaeus L.) (Hadi et al., 2013; Du \& Qian, 2010; Aprea, Biasiolli \& Gasperi, 2015). Terpenoids were dominant in the volatile profiles with similar amounts of ketones, aldehydes, esters and alcohols also present (Forney, 2001). The key compounds that contribute to the raspberry aroma include raspberry ketone (4-(4-hydroxyphenyl)butan-2-one), $\alpha$-ionone, $\beta$-ionone, linalool, (Z)-3-hexenol, geraniol, nerol, $\alpha$-terpineol, furaneol, hexanal, $\beta$-ocimine, 1 -octanol, $\beta$-pinene, $\beta$-damascenone, ethyl 2-methylpropanoate, (E )-2-hexenal, heptanal, and benzaldehyde. Raspberry ketone, 
$\alpha$-ionone, and $\beta$-ionone, which produce the sweet-smelling and floral aroma were determined to be the key aroma compounds in raspberry regardless of the cultivar and are characteristic of the raspberry aroma, while linalool and geraniol were detected in great amounts in some cultivars (Hadi et al., 2013; Du \& Qian, 2010; Aprea et al., 2015). Since raspberry ketone has a high boiling point, it may not be detected with certain analysis techniques (Forney, 2001).

Jetti et al. (2007) used HS-SPME-GC-MS to quantify select aroma-active compounds in ten strawberry cultivars grown in California and Oregon. Each sample was adsorbed onto a 50/30 $\mu \mathrm{m}$ divinylbenzene (DVB)/Carboxen (CAR)-polydimethylsiloxane (PDMS) fiber, extracted for $60 \mathrm{~min}$ at $50^{\circ} \mathrm{C}$, and desorbed for $3 \mathrm{~min}$ at $250^{\circ} \mathrm{C}$ in the GC injector. Aprea, Biasiolli, Carlin, Endrizzi \& Gasperi (2009) assessed headspace SPME-GC-MS for the analysis of two raspberry varieties and identified 28 compounds and tentatively identified 18 compounds present in the fruits. Extraction was performed using a SPME 50/30 $\mu \mathrm{m}$ (DVB/CAR-PDMS) fiber for $30 \mathrm{~min}$ at $35^{\circ} \mathrm{C}$ and desorption was for $5 \mathrm{~min}$ at $250^{\circ} \mathrm{C}$.

Freeze-drying has become of increasing interest among consumers (Ciurzyríska \& Lenart, 2011). Freeze-drying results in a high-quality food product and extended shelf-life because of the low temperature used in processing. The flavors, aroma, and nutritional content of the original product generally stay the same making the process popular for preserving food (Ciurzyríska \& Lenart, 2011). Freeze-drying is useful for fruits that are seasonal, such as strawberries and raspberries. In the last decade, FD strawberry and raspberry have become more prevalent in the food industry, for example, with dehydrated fruits being added to snacks, cereals and confectionary products.

The aim of this study was to determine the optimum extraction of volatile compounds in freeze-dried strawberries and raspberries to study their aroma profile, which is an important trait of fruit quality, by using HS-SPME-GC-MS.

\section{Materials and Methods}

\subsection{Samples and Chemicals}

Freeze-dried whole strawberries and whole raspberries were obtained from Van Drunen Farms (Momence, IL, USA). Furfural, ethyl hexanoate, 2,5-dimethyl-4-methoxy-3(2H)-furanone (mesifurane), gamma-decalactone, alpha-ionone, beta-ionone, and anisole (internal standard) were purchased from Sigma-Aldrich (St. Louis, MO, USA). Ultra-pure water was obtained from a Milli-Q system (Millipore, Bedford, MA, USA). Sodium carbonate anhydrous and methanol, HPLC grade were bought from Fisher Scientific (Hanover Park, IL, USA).

\subsection{SPME Fiber and Extraction Conditions Selection}

Aroma volatiles from the FD strawberry and raspberry samples were initially extracted using four types of SPME fibers, coated with different stationary phases: $100 \mu \mathrm{m}$ polydimethylsiloxane (PDMS), $65 \mu \mathrm{m}$ polydimethylsiloxane/divinylbenzene (PDMS/DVB), $85 \mu \mathrm{m}$ carboxen/polydimethylsiloxane (CAR/PDMS) and $50 / 30 \mu \mathrm{m}$ divinylbenzene/carboxen on polydimethylsiloxane on a StableFlex fiber (DVB/ CAR-DMS). These fibers were acquired from Supelco (Bellefonte, PA, USA). The fibers were conditioned before use according to manufacturer's instructions.

The sample $(1.0 \mathrm{~g})$ was weighed into a clear, $20 \mathrm{~mL}$ headspace vial (Gerstel, Linthicum, MD, USA), capped (magnetic crimp caps with PTFE septa, Gerstel, Linthicum, MD, USA), and placed on the headspace autosampler. The incubation time was $15 \mathrm{~min}$ at $60^{\circ} \mathrm{C}$. The fiber was exposed at four different times of $10,15,20$ and $30 \mathrm{~min}$ to the headspace of the sample and at three different temperatures of $40^{\circ} \mathrm{C}, 60^{\circ} \mathrm{C}$, and $80^{\circ} \mathrm{C}$. The desorption time was $10 \mathrm{~min}$ at $250^{\circ} \mathrm{C}$ in the $\mathrm{GC}$ inlet in the splitless mode.

\subsection{Sample Matrix Selection}

Whole freeze-dried sample (1.0 g) was weighed into a clear, $20 \mathrm{~mL}$ headspace vial (Gerstel, Linthicum, MD, USA), capped (magnetic crimp caps with PTFE septa, Gerstel, Linthicum, MD, USA), and placed on the headspace autosampler. In a second vial, the ground, powdered strawberry/raspberry sample $(1.0 \mathrm{~g})$ was weighed into a vial. In a third vial, $10 \mathrm{~mL}$ of distilled water was added to the sample $(1.0 \mathrm{~g})$. In a fourth vial, water was substituted for the salt solution ( $20 \%$ of sodium sulfate in distilled water). For all the trials, the headspace extraction was performed using the optimized extraction parameters $\left(15 \mathrm{~min}, 60^{\circ} \mathrm{C}\right)$ with a $50 / 30 \mu \mathrm{m}$ DVB/CAR-PDMS fiber ( $2 \mathrm{~cm}$, Supelco, Bellefonte, PA, USA) The desorption time was $10 \mathrm{~min}$ at $250^{\circ} \mathrm{C}$ in the GC inlet.

\subsection{Sample Preparation and SPME Extraction}

The FD sample $(1.0 \mathrm{~g})$ was placed into a clear, $20 \mathrm{~mL}$ headspace vial and an internal standard, anisole $(50 \mu \mathrm{g})$ 
was added. A 50/30 $\mu \mathrm{m}$ DVB/CAR-PDMS fiber (Supelco, Bellefonte, PA, USA) was chosen for aroma extraction. The sample was incubated for $15 \mathrm{~min}$ at $60^{\circ} \mathrm{C}$. The SPME fiber was then exposed at the agitation speed $(400 \mathrm{rpm})$ and optimized extraction time and temperature $\left(15 \mathrm{~min}, 60^{\circ} \mathrm{C}\right)$. Afterwards, the SPME fiber was desorbed through the injector port of the gas chromatography at $250^{\circ} \mathrm{C}$ for $10 \mathrm{~min}$ in the splitless mode.

\subsection{Quantitation}

Standard stock solutions of approximately $10,000 \mu \mathrm{g} / \mathrm{mL}$ of each select compound detected in FD strawberry (furfural, mesifurane, and gamma-decalactone) and FD raspberry (furfural, alpha-ionone and beta-ionone), and anisole (internal standard) were prepared in methanol. Working standards were prepared as mixtures so that final concentrations ranged from $0.01 \mu \mathrm{g} / \mathrm{mL}$ to $1000 \mu \mathrm{g} / \mathrm{mL}$. The calibration curve range was as follows: 5 to 1000 $\mu \mathrm{g} / \mathrm{mL}$ for mesifurane and furfural; 0.5 to $100 \mu \mathrm{g} / \mathrm{mL}$ for gamma-Decalactone; 0.01 to $5 \mu \mathrm{g} / \mathrm{mL}$ for $\alpha$-ionone and $\beta$-ionone. Fifty microliters of anisole (IS) was also added to each standard mixture for a final concentration of 5 $\mu \mathrm{g} / \mathrm{mL}$. After equilibration, the standards were extracted with SPME and analyzed by GC-MS as was done for the samples. Calibration curves were generated as a plot of ratio of concentration of analyte to the concentration of internal standard vs. ratio of peak area response of analyte to internal standard. These were used to quantitate the concentration of volatile compounds in the samples.

\subsection{Gas Chromatography-mass Spectrometry (GC-MS)}

The analysis of aroma volatiles extracted by HS-SPME was performed using a Model 7890A gas chromatograph (GC) equipped with a 5975C (G3440A) inert mass spectrometer detector (MSD) with a triple-axis detector (G3171A) (Agilent Technologies, Santa Clara, CA, USA). The GC was coupled with a Gerstel Multipurpose Sampler (MPS) (Linthicum, MD, USA) that had a SPME fiber holder. The injector port had a $2 \mathrm{~mm}$ deactivated $\mathrm{GC}$ liner and the inlet was kept at a constant temperature of $250^{\circ} \mathrm{C}$. A fused silica HP-5ms-UI column (30 $\mathrm{m} \mathrm{x}$ $0.25 \mathrm{~mm}$ ID x $0.25 \mu \mathrm{m}$ thick film), Agilent Technologies (Santa Clara, CA, USA) was used. Helium was the carrier gas with a flow rate of $1 \mathrm{~mL} / \mathrm{min}$.

The initial oven temperature was $40^{\circ} \mathrm{C}$ with a hold time of $5 \mathrm{~min}$. Then the temperature rose to $230^{\circ} \mathrm{C}$ at $10^{\circ} \mathrm{C} / \mathrm{min}$ for $5 \mathrm{~min}$ and increased again to $250^{\circ} \mathrm{C}$ at $10^{\circ} \mathrm{C} / \mathrm{min}$ for $5 \mathrm{~min}$.

The MSD operated in electron ionization mode at $70 \mathrm{ev}$. The MSD transfer line was set at $280^{\circ} \mathrm{C}$. The ion source was heated at $230^{\circ} \mathrm{C}$ and the MS quads were both heated at $150^{\circ} \mathrm{C}$. Solvent delay was $1.5 \mathrm{~min}$. The mass acquisition range was 20 to $450 \mathrm{~m} / \mathrm{z}$.

\subsection{Data Analysis}

Aroma volatile compound identification and quantitation were performed using Agilent Technologies' ChemStation software (version E.02.02.). Samples were prepared in triplicate for each analysis. Microsoft Excel 2016 (Redmond, WA, USA) was used for the calculation of means, standard deviations (SD) and relative standard deviations (\%RSD). Significant differences between samples were analyzed using analysis of variance (ANOVA) with Sigma Plot 14.0 (Systat Software; San Jose, CA, USA). The aroma volatile compounds were identified using the U.S. National Institute of Standards and Technology (NIST) Mass Spectral Library, v.2.3, 2017 in Chemstation. Authentic pure reference standards confirmed select volatile compounds in FD strawberry and FD raspberry samples.

\section{Results and Discussion}

\subsection{Fiber Type Selection}

A fiber's coating type and thickness is the most important feature that determines the analytical performance of SPME. The type of fiber used affects the selectivity of extraction. Generally, polar fibers are used for polar analytes and non-polar fibers for non-polar analytes similar to conventional GC stationary phases.

PDMS is best used for extracting non-polar analytes, such as volatile flavor compounds but also polar compounds using GC (Vas \&Vékey, 2004; Ducki, Miralles-Garcia, Zumbé, Tornero \& Storey, 2008). CAR/PDMS and PDMS/DVB have been used for extracting volatile low molecular mass and polar analytes. DVB/CAR-PDMS is composed of a layer of PDMS/DVB over a layer of CAR-PDMS and is used for odors and flavors (volatiles and non-volatiles) (Vas \&Vékey, 2004; Ducki et al., 2008). FD strawberry and FD raspberry samples were initially extracted using these four SPME fibers and analyzed by GC-MS to determine which fibers achieved the greatest performance for the recovery of aroma volatile compounds at the intermediate extraction time of $15 \mathrm{~min}$ and extraction temperature of $60^{\circ} \mathrm{C}$. Twenty-nine compounds in FD strawberry and 20 compounds in FD raspberry were extracted and tentatively identified based on their mass spectra (MS) (Table 1). These included terpenes, lactones, aldehydes, alcohols, acids, and furanones. 
Table 1. Effect of fiber type on the extraction of aroma volatile compounds peak areas (mean $\pm \% \mathrm{RSD}, \mathrm{n}=3$ ) in freeze-dried strawberry and raspberry for $15 \mathrm{~min}$ at $60^{\circ} \mathrm{C}$

\begin{tabular}{|c|c|c|c|c|c|c|c|c|c|c|c|c|c|c|c|}
\hline \multirow{3}{*}{$\begin{array}{l}\text { Compound } \\
\text { Furfural }\end{array}$} & \multicolumn{4}{|c|}{ 50/30um CAR/DVB/PDMS } & \multicolumn{4}{|c|}{ 65um PDMS/DVB } & \multicolumn{4}{|c|}{ 85um CAR/PDMS } & \multicolumn{3}{|l|}{$100 \mu \mathrm{m}$ PDMS } \\
\hline & \multicolumn{2}{|c|}{ Strawberry } & \multicolumn{2}{|l|}{ Raspberry } & \multicolumn{2}{|c|}{ Strawberry } & \multicolumn{2}{|c|}{ Raspberry } & \multicolumn{2}{|c|}{ Strawberry } & \multicolumn{2}{|l|}{ Raspberry } & Strawberry & \multicolumn{2}{|c|}{ Raspberry } \\
\hline & $\begin{array}{l}14287556 \\
3.62\end{array}$ & \pm & $\begin{array}{l}53944896 \\
16.77\end{array}$ & \pm & $\begin{array}{l}1048909 \\
17.56\end{array}$ & \pm & $\begin{array}{l}4834081 \\
13.19\end{array}$ & \pm & $\begin{array}{l}2450119 \\
70.95\end{array}$ & \pm & $\begin{array}{l}24918746 \\
13.08\end{array}$ & \pm & $\begin{array}{ll}52967 & \pm \\
49.38 & \end{array}$ & $\begin{array}{l}327748 \\
11.34\end{array}$ & \pm \\
\hline $\begin{array}{l}\text { Oxime,methoxy-ph } \\
\text { enyl }\end{array}$ & ND & & $\begin{array}{l}1431976 \\
7.70\end{array}$ & \pm & ND & & $\begin{array}{l}456634 \\
5.03\end{array}$ & \pm & ND & & $\begin{array}{l}572142 \\
4.10\end{array}$ & \pm & ND & $\begin{array}{l}138760 \\
13.04\end{array}$ & \pm \\
\hline $\begin{array}{l}\text { Methyl hexanoate } \\
\text { (hexanoic acid, } \\
\text { methyl ester) }\end{array}$ & $\begin{array}{l}906604 \\
14.36\end{array}$ & \pm & ND & & $\begin{array}{l}85330 \\
76.24\end{array}$ & \pm & ND & & $\begin{array}{l}214907 \\
29.27\end{array}$ & \pm & ND & & $9740 \pm 19.48$ & ND & \\
\hline $\begin{array}{l}3(2 \mathrm{H}) \text {-furanone,2(1 } \\
\text {-hydroxy-1-methyl- } \\
\text { 2-oxopropyl)-2,5-di } \\
\text { methyl }\end{array}$ & $\begin{array}{l}4721280 \\
7.83\end{array}$ & \pm & ND & & $\begin{array}{l}541481 \\
8.29\end{array}$ & \pm & ND & & $\begin{array}{l}1021527 \\
17.87\end{array}$ & \pm & ND & & $46018 \pm 5.2$ & ND & \\
\hline $\begin{array}{l}\text { 2,4-dihydroxy-2,5-d } \\
\text { imethyl-3(2H)-fura } \\
\text { n-3-one }\end{array}$ & $\begin{array}{l}3770591 \\
11.67\end{array}$ & \pm & $\begin{array}{l}2394817 \\
8.03\end{array}$ & \pm & $\begin{array}{l}445807 \\
18.82\end{array}$ & \pm & $\begin{array}{l}434187 \\
18.12\end{array}$ & \pm & $\begin{array}{l}220305 \\
73.62\end{array}$ & \pm & $\begin{array}{l}102113 \\
27.68\end{array}$ & \pm & $36041 \pm 24.1$ & $\begin{array}{l}8276 \\
22.91\end{array}$ & \pm \\
\hline $\begin{array}{l}\text { Ethyl hexanoate } \\
\text { (hexanoic acid, } \\
\text { ethyl ester) }\end{array}$ & $\begin{array}{l}3065190 \\
26.97\end{array}$ & \pm & ND & & $\begin{array}{l}253103 \\
30.70\end{array}$ & \pm & ND & & $\begin{array}{l}466822 \\
32.20\end{array}$ & \pm & ND & & $20606 \pm 34.4$ & ND & \\
\hline $\begin{array}{l}\text { Hexyl acetate } \\
\text { (acetic acid, hexyl } \\
\text { ester) }\end{array}$ & $\begin{array}{l}2622895 \\
35.26\end{array}$ & \pm & ND & & $\begin{array}{l}264464 \\
63.24\end{array}$ & \pm & ND & & $\begin{array}{l}293391 \\
12.79\end{array}$ & \pm & ND & & $25512 \pm 16.8$ & ND & \\
\hline $\begin{array}{l}\text { 2,5-Dimethyl-4-met } \\
\text { hoxy-3(2H)-furano } \\
\text { ne (Mesifurane) }\end{array}$ & $\begin{array}{l}24928055 \\
2.29\end{array}$ & \pm & ND & & $\begin{array}{l}3507881 \\
15.31\end{array}$ & \pm & ND & & $\begin{array}{l}5143420 \\
12.63\end{array}$ & \pm & ND & & $\begin{array}{l}321602 \quad \pm \\
20.7\end{array}$ & ND & \\
\hline Nonanal & $\begin{array}{l}2838635 \\
7.56\end{array}$ & \pm & $\begin{array}{l}1130253 \\
9.54\end{array}$ & \pm & $\begin{array}{l}271579 \\
22.81\end{array}$ & \pm & $\begin{array}{l}142880 \\
12.92\end{array}$ & \pm & $\begin{array}{l}103200 \\
21.55\end{array}$ & \pm & $\begin{array}{l}103457 \\
1.07\end{array}$ & \pm & $39141 \pm 18.4$ & $\begin{array}{l}24245 \\
13.40\end{array}$ & \pm \\
\hline $\begin{array}{l}\text { 4H-pyran-4-one, } 2,3 \\
\text {-dihydro-3,5-dihydr } \\
\text { oxy-6-methyl- }\end{array}$ & $\begin{array}{l}2554730 \\
9.82\end{array}$ & \pm & $\begin{array}{l}2228400 \\
10.16\end{array}$ & \pm & $\begin{array}{l}419541 \\
2.74\end{array}$ & \pm & $\begin{array}{l}349589 \\
1.97\end{array}$ & \pm & $\begin{array}{l}245745 \\
8.99\end{array}$ & \pm & $\begin{array}{l}236018 \\
15.29\end{array}$ & \pm & $10756 \pm 23.9$ & $\begin{array}{l}9177 \\
15.50\end{array}$ & \pm \\
\hline $\begin{array}{l}\text { Benzyl acetate } \\
\text { (acetic acid, } \\
\text { phenylmethyl ester) }\end{array}$ & $\begin{array}{l}138063 \\
40.19\end{array}$ & \pm & & & $\begin{array}{l}47002 \\
21.78\end{array}$ & \pm & & & $\begin{array}{l}27632 \\
26.48\end{array}$ & \pm & & & $5359 \pm 12.0$ & & \\
\hline $\begin{array}{l}\text { 5-Hydroxymethyl } \\
\text { furfural }\end{array}$ & $\begin{array}{l}414631 \\
14.13\end{array}$ & \pm & $\begin{array}{l}2184792 \\
21.98\end{array}$ & \pm & $\begin{array}{l}228793 \\
9.48\end{array}$ & \pm & $\begin{array}{l}991878 \\
14.30\end{array}$ & \pm & $\begin{array}{l}35652 \\
15.05\end{array}$ & \pm & $\begin{array}{l}202107 \\
17.57\end{array}$ & \pm & $7170 \pm 11.4$ & $\begin{array}{l}68077 \\
11.78\end{array}$ & \pm \\
\hline $\begin{array}{l}\text { Propanoic acid, } \\
\text { 2-methyl-, } \\
\text { 3--hydroxy-2,2,4-tri } \\
\text { methylpentyl ester }\end{array}$ & $\begin{array}{l}593540 \\
8.01\end{array}$ & \pm & $\begin{array}{l}366659 \\
9.53\end{array}$ & \pm & $\begin{array}{l}93218 \\
1.74\end{array}$ & \pm & $\begin{array}{l}73157 \\
4.56\end{array}$ & \pm & $\begin{array}{l}76348 \\
3.73\end{array}$ & \pm & $58162 \pm 8$ & & $33977 \pm 9.30$ & $\begin{array}{l}22143 \\
1.85\end{array}$ & \pm \\
\hline $\begin{array}{l}\text { Octyl } \\
\text { 2-methylbutanoate }\end{array}$ & $\begin{array}{l}1604694 \\
25.19\end{array}$ & \pm & ND & & $\begin{array}{l}319792 \\
20.98\end{array}$ & \pm & ND & & $\begin{array}{l}161766 \\
28.54\end{array}$ & \pm & ND & & $\begin{array}{l}230321 \\
37.92\end{array}$ & ND & \\
\hline $\begin{array}{l}\text { 2-furancarboxaldeh } \\
\text { yde,5-methyl }\end{array}$ & ND & & $\begin{array}{l}300985 \\
17.89\end{array}$ & \pm & ND & & $\begin{array}{l}352918 \\
25.57\end{array}$ & \pm & ND & & $\begin{array}{l}187987 \\
13.77\end{array}$ & \pm & ND & $\begin{array}{l}14855 \\
17.81\end{array}$ & \pm \\
\hline $\begin{array}{l}\text { Ethanol,2-(hexylox } \\
\text { yl-) }\end{array}$ & ND & & $\begin{array}{l}1173046 \\
18.79\end{array}$ & \pm & ND & & $\begin{array}{l}215500 \\
4.91\end{array}$ & \pm & ND & & $\begin{array}{l}115225 \\
4.03\end{array}$ & \pm & ND & $\begin{array}{l}23213 \\
5.25\end{array}$ & \pm \\
\hline $\begin{array}{l}\text { 2H-pyran-2-one,tetr } \\
\text { ahydro-6-propyl }\end{array}$ & ND & & $\begin{array}{l}2984231 \\
28.05\end{array}$ & \pm & ND & & $\begin{array}{l}359921 \\
31.83\end{array}$ & \pm & ND & & $\begin{array}{l}189780 \\
23.91\end{array}$ & \pm & ND & $\begin{array}{l}124500 \\
5.95\end{array}$ & \pm \\
\hline$\gamma$-Decalactone & $\begin{array}{l}1289139 \\
5.02\end{array}$ & \pm & ND & & $\begin{array}{l}468706 \\
81.85\end{array}$ & \pm & ND & & $\begin{array}{l}78841 \\
23.63\end{array}$ & \pm & ND & & $\begin{array}{l}281219 \\
70.22\end{array}$ & ND & \\
\hline $\begin{array}{l}\text { 2-Furanmethanol,te } \\
\text { trahydro- } \alpha, \alpha, 5 \text {-trim } \\
\text { ethyl-5-(4-methyl-3 } \\
\text {-cyclohexen-1-yl)-[ } \\
\text { 2s-[2 } \alpha, 5 \beta(\mathrm{R}))]\end{array}$ & $\begin{array}{l}1049749 \\
16.92\end{array}$ & \pm & ND & & $\begin{array}{l}52256 \\
3.67\end{array}$ & \pm & ND & & $\begin{array}{l}16402 \\
30.54\end{array}$ & \pm & ND & & $\begin{array}{l}70927 \\
12.96\end{array}$ & ND & \\
\hline Caryophyllene & ND & & $\begin{array}{l}47485 \\
20.69\end{array}$ & \pm & ND & & $\begin{array}{l}39877 \\
13.85\end{array}$ & \pm & $\mathrm{ND}$ & & $\begin{array}{l}63030 \\
30.78\end{array}$ & \pm & ND & $\begin{array}{l}23648 \\
15.43\end{array}$ & \pm \\
\hline$\alpha$-Ionone & ND & & $\begin{array}{l}4097353 \\
18.96\end{array}$ & \pm & ND & & $\begin{array}{l}590635 \\
11.81\end{array}$ & \pm & ND & & $\begin{array}{l}718633 \\
13.63\end{array}$ & \pm & ND & $\begin{array}{l}631754 \\
19.83\end{array}$ & \pm \\
\hline$\beta$-Ionone & ND & & $\begin{array}{l}5489049 \\
10.47\end{array}$ & \pm & ND & & $\begin{array}{l}1175454 \\
6.88\end{array}$ & \pm & ND & & $\begin{array}{l}840167 \\
28.67\end{array}$ & \pm & ND & $\begin{array}{l}953036 \\
18.21\end{array}$ & \pm \\
\hline$\gamma$-Dodecalactone & $\begin{array}{l}492529 \\
18.84\end{array}$ & \pm & & & $\begin{array}{l}171680 \\
26.33\end{array}$ & \pm & & & $\begin{array}{l}20976 \\
26.98\end{array}$ & \pm & & & $\begin{array}{l}227406 \\
5.40\end{array}$ & & \\
\hline $\begin{array}{l}\text { 7,9-Di-tert-butyl-ox } \\
\text { aspiro(4,5)-deca-6,9 } \\
\text {-diene-2,8-dione }\end{array}$ & $\begin{array}{l}242324 \\
21.53\end{array}$ & \pm & $\begin{array}{l}155720 \\
9.52\end{array}$ & \pm & $\begin{array}{l}17009 \\
9.77\end{array}$ & \pm & $\begin{array}{l}23496 \\
5.77\end{array}$ & \pm & $3389 \pm 6$ & & $3611 \pm 22$ & & $16251 \pm 9.58$ & $\begin{array}{l}26290 \\
3.37\end{array}$ & \pm \\
\hline Total & 65520205 & & 68187540 & & 8236551 & & 10040207 & & 10580442 & & 28311178 & & 1435013 & 2395722 & \\
\hline
\end{tabular}

ND- not detected

An examination of the total peak area for each fiber showed that the most efficient fiber is $50 / 30 \mu \mathrm{m}$ DVB/CAR-PDMS, extracting eight times more than the $65 \mu \mathrm{m}$ PDMS/DVB, about seven times more than the 85 
$\mu \mathrm{m}$ CAR/PDMS and 45 times more than the $100 \mu \mathrm{m}$ PDMS fiber for volatiles in strawberry. The fiber that was the best performer for extracting volatiles in raspberry was also 50/30 $\mu \mathrm{m}$ DVB/CAR-PDMS, extracting seven times more than the $65 \mu \mathrm{m}$ PDMS/ DVB, two times more than the $85 \mu \mathrm{m}$ CAR/PDMS and 28 times more than the $100 \mu \mathrm{m}$ PDMS fiber. Extraction with the PDMS fiber was very weak compared to the other three fibers shown by the very low peak responses. The DVB/CAR-PDMS fiber extracted the most analytes (total peak area $65,520,205$ for strawberry and $68,187,540$ for raspberry) and proved to be very capable at extracting volatiles. This is in agreement with other studies of aroma volatile compounds, which identified the DVB/CAR-PDMS fiber as the best fiber for extraction in cocoa products, strawberry fruit, mushrooms, olive oil, and raspberry fruits and juices (Ducki et al., 2008; Jetti et al., 2007; Aisala, Sola, Hopia, Linderborg \& Sandell, 2019; Sanz, Belaj, Sánchez-Ortiz, Pérez, 2018; Du et al., 2011; Aprea et al., 2009). Therefore, it was decided that this fiber would be used to establish the aroma volatile profiles of FD strawberry and raspberry.

Mesifurane and 2,5-dimethyl-4-hydroxy-3(2H)-furanone (furaneol) are two most important furanones in fresh strawberry (Jetti et al., 2007). In this study, the two major aroma compounds in FD strawberry are shown to be 2,5-dimethyl-4-methoxy-3(2H)-furanone (Mesifurane) and furfural and represent $38.1 \%$ and $21.8 \%$ of the total volatiles in FD strawberry, respectively. Furaneol was not detected in the FD strawberry samples. This may be because furaneol is heat labile and is unstable both in the presence of air and in aqueous solutions (Forney, 2001; Weerawatanakorn, Wu, Pan \& Ho, 2015) or it may not be detected with this HS-SPME-GC-MS method (Jouquand \& Chandler, 2008). Other furanones, 3(2H)-furanone, 2(1-hydroxy-1-methyl-2-oxopropyl)-2,5-dimethyl, 2,4-dihydroxy-2,5-dimethyl-3(2H)-furan-3-one, and gamma-decalactone $(2(3 \mathrm{H})$-furanone, 5-hexyldihydro-) comprise about $15.0 \%$ of the total volatiles in FD strawberry. Other compounds identified in fresh strawberries and similarly in the FD product in this study include esters, pyranones, lactones, and other minor components (Jetti et al., 2007). In his study, Forney (2001) determined that fresh strawberry contained 1-30\% furanones, $10-30 \%$ alcohols with the highest total abundance being $15-70 \%$ of esters.

In FD raspberry, furfural comprises $64.9 \%$ of the total content of volatile compounds, $\beta$-Ionone $8.0 \%$ and $\alpha$-Ionone $6.0 \%$ as is typical of the compounds of fresh raspberry (Hadi et al., 2013; Forney, 2001; Du \& Qian, 2010). Pyranones, 2H-pyran-2-one,tetrahydro-6-propyl and 4H-pyran-4-one, 2,3-dihydro-3,5-dihydroxy-6-methyl constitute $7.6 \%$ of the total content of volatiles in FD raspberry. Other compounds found in the FD raspberry sample in this analysis include oxime, 5-hydroxymethyl furfural, aldehydes, ethanol and other minor analytes. In his study, Forney (2001) showed that fresh raspberry constituted 2-40\% alcohols, 5-15\% esters and ketones, 10-20\% aldehydes, with the most abundance being 20-50\% terpenoids.

Similar volatile compounds detected in both FD berry samples but containing different quantities are furfural, 5-hydroxymethyl furfural, nonanal, 2,4-dihydroxy-2,5-dimethyl-3(2H)-furan-3one, and 4H-pyran-4-one, 2,3-dihydro-3,5-dihydroxy-6-methyl. The volatile profiles of fresh berries depend on the cultivar, ripeness, environmental conditions, fruit matrices (whole, slices or homogenized) and analytical methods used for identification (Hadi et al., 2013; Jetti et al., 2007; Jouquand \& Chandler, 2008; Forney, 2001; Du \& Qian, 2010).

\subsection{SPME Extraction Time and Temperature Selection}

Extraction time and temperature are two critical variables that influence sample recovery by the SPME fibers. Therefore, these two parameters were examined to determine the optimum extraction conditions.

Extraction times were examined at $10,15,20$, and $30 \mathrm{~min}$ and at three different temperatures $\left(40^{\circ} \mathrm{C}, 60^{\circ} \mathrm{C}\right.$, and $80^{\circ} \mathrm{C}$ ). The $50 / 30 \mu \mathrm{m}$ DVB/CAR-PDMS fiber was chosen for the extraction of volatile compounds in the FD strawberry and raspberry samples because usually, the thinnest fiber is used to reduce extraction times (Vas \& Vékey, 2004). This was shown in this study where most of the compounds in FD strawberry and raspberry required only $15 \mathrm{~min}$ of extraction time generating high peak area responses. This was similar to the findings of Ducki et al. (2008) who noticed that after 20 min there was a decline in the amount of volatiles extracted and the semi-volatiles took 30 min to be extracted with the DVB/CAR-PDMS fiber for cocoa products. Ducki et. al (2008) extracted for 15 min compounds from the cocoa products both volatile and semi-volatiles compounds. Initial results of this study showed that using $65 \mu \mathrm{m}$ PDMS/DVB, $85 \mu \mathrm{m}$ CAR/PDMS and $100 \mu \mathrm{m}$ PDMS would require longer extraction times (up to $30 \mathrm{~min}$ ) for some volatile compounds in FD strawberry and raspberry (data not shown). It was, therefore, decided that the 50/30 $\mu \mathrm{m}$ DVB/CAR-PDMS fiber was the best option for extraction of volatiles in FD strawberry and raspberry for $15 \mathrm{~min}$.

Comparable to the cocoa products study of Ducki et. al (2008), it was determined that the amount of volatile compounds extracted increases greatly with the temperature of extraction. The optimum extraction temperature was at $60^{\circ} \mathrm{C}$ in this study and $80^{\circ} \mathrm{C}$ in the cocoa products study. However, $80^{\circ} \mathrm{C}$ was not applied for the 
extraction of cocoa products since chemical changes were likely to occur in the sample at this high temperature but $60^{\circ} \mathrm{C}$ was used (Ducki et al., 2008).

Only eight compounds were tentatively identified at $40^{\circ} \mathrm{C}$ in strawberry with the lowest peak counts being for ethanol, 2-(2-butoxethoxy)- and butanoic acid, 3-methyl,-octyl ester (Table 2). Most of the peak area responses for compounds such as alcohols, acids, terpenes and some esters are higher at $80^{\circ} \mathrm{C}$ than at $60^{\circ} \mathrm{C}$. However, at $80^{\circ} \mathrm{C}, 21$ compounds are identified in strawberry out of the 29 peaks that are identified at $60^{\circ} \mathrm{C}$. Mesifurane, a characteristic aroma compound for strawberry, has a higher peak response at the $60^{\circ} \mathrm{C}$ temperature. A decision was therefore made to use $60^{\circ} \mathrm{C}$ as the optimum temperature for extraction of volatiles from strawberry with the 50/30 $\mu \mathrm{m}$ DVB/CAR-PDMS fiber.

Table 2. Effect of temperature on the extraction efficiency of major compounds in FD strawberry (peak area $\pm \%$ RSD), $\mathrm{n}=3.50 / 30 \mathrm{um}$ DVB/CAR-PDMS fiber was used, and $15 \mathrm{~min}$ for extraction time

\begin{tabular}{|c|c|c|c|}
\hline Compound & $40^{\circ} \mathrm{C}$ & $60^{\circ} \mathrm{C}$ & $80^{\circ} \mathrm{C}$ \\
\hline Butanoic acid, ethyl ester & ND & $3559721 \pm 77.00$ & ND \\
\hline Furfural & ND & $19445182 \pm 53.31$ & ND \\
\hline Oxime,methoxy-phenyl & $338625 \pm 8.79^{\mathrm{a}}$ & $1440284 \pm 37.24^{\mathrm{b}}$ & $276022 \pm 15.91^{\mathrm{a}}$ \\
\hline Methyl hexanoate & ND & $730820 \pm 13.11^{\mathrm{a}}$ & $1670709 \pm 8.59^{\mathrm{b}}$ \\
\hline 3(2H)-furanone,2(1-hydroxy-1-methyl-2-oxopropyl)-2,5-dimethyl & ND & $4452794 \pm 3.21$ & ND \\
\hline 2,4-dihydroxy-2,5-dimethyl-3(2H)-furan-3-one & ND & $3107453 \pm 35.95$ & ND \\
\hline Ethyl hexanoate & ND & $3623295 \pm 24.44$ & ND \\
\hline Hexyl acetate & ND & $634125 \pm 9.51^{\mathrm{a}}$ & $5853577 \pm 8.80^{\mathrm{b}}$ \\
\hline 2-hexen-1-ol,acetate & $18775 \pm 36.05^{\mathrm{a}}$ & $2000819 \pm 22.16^{\mathrm{b}}$ & $8652248 \pm 6.97^{\mathrm{c}}$ \\
\hline 3(2H)-furanone,-4-methoxy-2,5-dimethyl (Mesifurane) & $451560 \pm 27.03^{\mathrm{a}}$ & $6600808 \pm 19.54^{\mathrm{b}}$ & $3287796 \pm 48.12^{\mathrm{c}}$ \\
\hline 1-Octanol & ND & $3137311 \pm 64.31^{\mathrm{a}}$ & $6065952 \pm 6.80^{\mathrm{a}}$ \\
\hline Linalool & ND & $1151138 \pm 14.17^{\mathrm{a}}$ & $14688297 \pm 1.81^{\mathrm{b}}$ \\
\hline Nonanal & $332160 \pm 31.96^{\mathrm{a}}$ & $2497489 \pm 5.04^{\mathrm{b}}$ & $17803476 \pm 10.12^{\mathrm{c}}$ \\
\hline 4H-pyran-4-one,2,3-dihydro-3,5-dihydroxy-6-methyl- & ND & $73012 \pm 33.89$ & ND \\
\hline Ethanol,2-(2-butoxyethoxy)- & $12951 \pm 12.89^{\mathrm{a}}$ & $607885 \pm 37.54^{\mathrm{b}}$ & $1924287 \pm 20.92^{\mathrm{c}}$ \\
\hline L-alpha-terpineol & ND & $45966 \pm 44.51^{\mathrm{a}}$ & $3963813 \pm 12.19^{\mathrm{b}}$ \\
\hline Decanal & ND & $1746636 \pm 28.76^{\mathrm{a}}$ & $1938806 \pm 3.17^{\mathrm{b}}$ \\
\hline Acetic acid, octyl ester & ND & $534955 \pm 13.13^{\mathrm{a}}$ & $5113712 \pm 19.21^{\mathrm{b}}$ \\
\hline 5-hydroxymethyl furfural & ND & $366275 \pm 28.45$ & ND \\
\hline Propanoic acid, 2-methyl-, 3--hydroxy-2,2,4-trimethylpentyl ester & $197162 \pm 4.11^{\mathrm{a}}$ & $538535 \pm 5.02^{\mathrm{b}}$ & ND \\
\hline Butanoic acid, octyl ester & ND & $1271621 \pm 25.06^{\mathrm{a}}$ & $6178825 \pm 44.04^{\mathrm{b}}$ \\
\hline Octyl 2-methylbutanoate & $48756 \pm 25.42^{\mathrm{a}}$ & $1478588 \pm 11.66^{\mathrm{b}}$ & $456629 \pm 17.79^{\mathrm{c}}$ \\
\hline Butanoic acid, 3-methyl, -octyl ester & $12365 \pm 5.54^{\mathrm{a}}$ & $46941 \pm 16.93^{\mathrm{b}}$ & $2132722 \pm 6.66^{\mathrm{c}}$ \\
\hline gamma-Decalactone (2(3H)-furanone, 5-hexyldihydro-) & ND & $10689 \pm 49.65^{\mathrm{a}}$ & $3587471 \pm 6.32^{\mathrm{b}}$ \\
\hline 1,6,10-dodecatrien-3 ol, 3,7-11 trimethyl ( E ) & ND & $2856563 \pm 8.47^{\mathrm{a}}$ & $29634692 \pm 3.50^{\mathrm{b}}$ \\
\hline Hexanoic acid,octyl ester & ND & $341559 \pm 30.29^{\mathrm{a}}$ & $2113772 \pm 10.52^{\mathrm{b}}$ \\
\hline Butanoic acid,decyl ester & ND & $31801 \pm 31.59^{\mathrm{a}}$ & $1031738 \pm 20.85^{\mathrm{b}}$ \\
\hline$\gamma$-Dodecalactone & ND & $23203 \pm 12.02^{\mathrm{a}}$ & $2697754 \pm 5.35^{\mathrm{b}}$ \\
\hline 7,9-Di-tert-butyl-oxaspiro(4,5)-deca-6,9-diene-2,8-dione & ND & $162122 \pm 15.63^{\mathrm{a}}$ & $1124296 \pm 5.79^{\mathrm{b}}$ \\
\hline
\end{tabular}

Values followed by different letters denote significant difference $\mathrm{p}<0.05$ for each analyte in FD strawberry across the rows and those followed by same letters denote no significant difference.

Fourteen out of 20 volatile compounds were tentatively identified at $40^{\circ} \mathrm{C}$ in raspberry with the lowest peak responses being for the terpenes (caryophyllene, $\alpha$-ionone, $\beta$-ionone) (Table 3). Undetected compounds were mostly the furanones. Peak area responses were higher for terpenes at $80^{\circ} \mathrm{C}$, except for D-Limonene and $\alpha$-ionone, which had the same responses at both $60^{\circ} \mathrm{C}$ and $80^{\circ} \mathrm{C}$. Since there were some undetectable compounds at $80^{\circ} \mathrm{C}$, it was determined that $60^{\circ} \mathrm{C}$ was the best extraction temperature of volatiles from raspberry with the 50/30 $\mu \mathrm{m}$ DVB/CAR-PDMS fiber. 
Table 3. Effect of temperature on the extraction efficiency of major compounds in FD raspberry (peak area $\pm \%$ RSD), $n=3.50 / 30$ um DVB/CAR-PDMS fiber was used, and $15 \mathrm{~min}$ for extraction time

\begin{tabular}{|c|c|c|c|}
\hline Compound & $40^{\circ} \mathrm{C}$ & $60^{\circ} \mathrm{C}$ & $80^{\circ} \mathrm{C}$ \\
\hline Furfural & ND & $53225620 \pm 15.81^{\mathrm{a}}$ & $27834234 \pm 11.59^{b}$ \\
\hline Oxime,methoxy-phenyl & $416878 \pm 15.20^{\mathrm{a}}$ & $2133051 \pm 16.67^{\mathrm{b}}$ & $9876478 \pm 6.08^{\mathrm{c}}$ \\
\hline 2-Furancarboxaldehyde, 5-methyl & ND & $999647 \pm 16.07$ & ND \\
\hline 2,4-Dihydroxy-2,5-dimethyl-3(2H)-furan-3one & ND & $2955337 \pm 8.31$ & ND \\
\hline alpha-Phellandrene & $72968 \pm 6.90^{\mathrm{a}}$ & $6652327 \pm 7.51^{\mathrm{b}}$ & $9924240 \pm 27.59^{c}$ \\
\hline o-Cymene & $686626 \pm 40.69^{\mathrm{a}}$ & $2270296 \pm 10.50^{\mathrm{b}}$ & $1995020 \pm 23.79^{\mathrm{b}}$ \\
\hline D-Limonene & $2928818 \pm 9.32^{\mathrm{a}}$ & $6512046 \pm 8.17^{\mathrm{a}}$ & $6865122 \pm 66.30^{\mathrm{a}}$ \\
\hline 2(3H)-furanone dihydro, 3-hydroxy-4,4-dimethyl & ND & $1246083 \pm 13.46^{\mathrm{a}}$ & $12990448 \pm 15.63^{\mathrm{b}}$ \\
\hline Linalool & ND & $156305 \pm 0.63^{\mathrm{a}}$ & $3593803 \pm 96.99^{\mathrm{b}}$ \\
\hline Nonanal & $144320 \pm 1.67^{\mathrm{a}}$ & $1083346 \pm 6.13^{\mathrm{b}}$ & $4612337 \pm 21.91^{\mathrm{c}}$ \\
\hline Ethanol,2-(hexyloxyl-) & $234079 \pm 3.55^{\mathrm{a}}$ & $1305104 \pm 5.93^{\mathrm{b}}$ & ND \\
\hline 4H-pyran-4-one, 2,3-dihydro-3,5-dihydroxy-6-methyl & $284308 \pm 4.23^{\mathrm{a}}$ & $2206587 \pm 8.26^{\mathrm{b}}$ & $260719 \pm 16.81^{\mathrm{a}}$ \\
\hline 5-Hydroxymethyl furan & ND & $2279812 \pm 21.50$ & ND \\
\hline 2H-pyran-2-one,tetrahydro-6-propyl & $199953 \pm 19.32^{\mathrm{a}}$ & $2000300 \pm 43.16^{\mathrm{b}}$ & ND \\
\hline Propanoic acid, 2-methyl-, 3-hydroxy-2,2,4-trimethylpentyl ester & $168991 \pm 8.09^{\mathrm{a}}$ & $408804 \pm 3.73^{\mathrm{b}}$ & ND \\
\hline Caryophyllene & $55663 \pm 28.17^{\mathrm{a}}$ & $979518 \pm 15.38^{\mathrm{b}}$ & $2636674 \pm 76.05^{\mathrm{c}}$ \\
\hline$\alpha$-Ionone & $31494 \pm 22.57^{\mathrm{a}}$ & $4196839 \pm 14.42^{\mathrm{b}}$ & $42919853 \pm 24.00^{\mathrm{b}}$ \\
\hline trans- $\beta$-Ionone & $86404 \pm 21.02^{\mathrm{a}}$ & $5530591 \pm 11.66^{\mathrm{b}}$ & $71217494 \pm 11.45^{\mathrm{c}}$ \\
\hline 2H-pyran-2-one,tetrahydro-6-pentyl & $52833 \pm 19.15^{\mathrm{a}}$ & $2059400 \pm 12.87^{\mathrm{b}}$ & $4024666 \pm 28.54^{\mathrm{b}}$ \\
\hline 7,9-Di-tert-butyl-oxaspiro(4,5)-deca-6,9-diene-2,8-dione & ND & $156263 \pm 9.80^{\mathrm{a}}$ & $144566 \pm 5.07^{\mathrm{a}}$ \\
\hline
\end{tabular}

ND- not detected

Values followed by different letters denote significant difference $\mathrm{p}<0.05$ for each analyte in FD strawberry across the rows and those followed by same letters denote no significant difference.

\subsection{Whole, Dry, Wet and Brine Conditions}

In order to understand the influence of dry or wet matrices on the headspace analysis of aroma volatile compounds, samples were analyzed in dry (whole and powder form) and in wet (whole in water and whole in brine) matrices. Similar, select volatile compounds were identified and the peak areas were compared with the dry and wet matrices in both FD strawberry and raspberry samples.

Twenty-nine analytes were tentatively identified in the dry matrices in FD strawberry (Table 4). Eight out of 29 analytes were not detected in the water matrix, and seven out of 29 were not detected in the salt matrix. These included furfural, furanones (3(2H)-furanone,2(1-hydroxy-1-methyl-2-oxopropyl)-2,5-dimethyl, 4H-pyran-4-one,2,3-dihydro-3,5-dihydroxy-6-methyl-, ethanol, and 5-hydroxymethyl furfural 2-(2-butoxyethoxy)-), L-alpha-terpineol, linalool, and decanal, which are soluble in water and are not able to go to the headspace for extraction even when salt was added. Of the 21 volatile compounds detected, the peak area response for the compounds extracted by the fiber in FD strawberry was slightly higher for dry matrices (11 compounds) than for wet matrices (10 compounds). Similarly, Ducki et al. (2008) reported that the amount of compounds in dry cocoa products extracted by the fiber was higher than under wet conditions. When FD strawberry was extracted as whole and powder samples, significant differences $(p<0.05)$ in the peak areas existed for 11 of the volatile compounds. 
Table 4. Comparison of the effect of different matrices (whole, powder, whole and water, and whole and $20 \%$ sodium sulfate) on the SPME extraction efficiency of key volatile compounds in FD strawberry (Peak area $\pm \% \mathrm{RSD}), \mathrm{n}=3.50 / 30 \mathrm{um} \mathrm{DVB} / \mathrm{CAR}-\mathrm{PDMS}$ fiber was used with $15 \mathrm{~min}$ for extraction time at $60^{\circ} \mathrm{C}$

\begin{tabular}{|c|c|c|c|c|}
\hline Compound & Whole & Powder & Whole in Water & $\begin{array}{l}\text { Whole in } 20 \% \\
\text { Sodium Sulfate } \\
\end{array}$ \\
\hline Butanoic acid, ethyl ester & $3559721 \pm 77.00^{\mathrm{a}}$ & $10923952 \pm 0.03^{\mathrm{b}}$ & $13795932 \pm 9.55^{\mathrm{c}}$ & $15021562 \pm 8.85^{\mathrm{b}, \mathrm{c}}$ \\
\hline Furfural & $19445182 \pm 53.31^{\mathrm{a}}$ & $6532651 \pm 40.95^{\mathrm{a}}$ & ND & ND \\
\hline Oxime,methoxy-phenyl & $1440284 \pm 37.24^{\mathrm{a}}$ & $1240125 \pm 3.55^{\mathrm{a}}$ & $5742229 \pm 5.63^{\mathrm{b}}$ & $7851299 \pm 11.53^{c}$ \\
\hline Methyl hexanoate & $730820 \pm 13.11^{\mathrm{a}}$ & $1891277 \pm 0.63^{\mathrm{a}}$ & $1054803 \pm 36.19^{\mathrm{a}}$ & $847980 \pm 11.95^{\mathrm{a}}$ \\
\hline 3(2H)-furanone,2(1-hydroxy-1-methy & $4452794 \pm 3.21^{\mathrm{a}}$ & $4669995 \pm 3.24^{\mathrm{a}}$ & ND & ND \\
\hline \multicolumn{5}{|l|}{ 1-2-oxopropyl)-2,5-dimethyl } \\
\hline 2,4-dihydroxy-2,5-dimethyl-3(2H)-furan-3-one & $3107453 \pm 35.95^{\mathrm{a}}$ & $6279950 \pm 2.67^{\mathrm{b}}$ & $2946616 \pm 22.22^{\mathrm{acc}}$ & $1859292 \pm 40.81^{\mathrm{c}}$ \\
\hline Ethyl hexanoate & $3623295 \pm 24.44^{\mathrm{a}}$ & $6509357 \pm 6.44^{\mathrm{b}}$ & $5878222 \pm 24.23^{\mathrm{b}}$ & $1757713 \pm 1.33^{\mathrm{a}}$ \\
\hline Hexyl acetate & $634125 \pm 9.51^{\mathrm{a}}$ & $2627191 \pm 2.14^{\mathrm{b}}$ & $3346907 \pm 28.07^{\mathrm{b}}$ & $3263514 \pm 17.82^{\mathrm{b}}$ \\
\hline 2-Hexen-1-ol,acetate & $2000819 \pm 22.16^{\mathrm{a}}$ & $4846235 \pm 0.77^{\mathrm{b}}$ & $1704739 \pm 91.45^{\mathrm{a}, \mathrm{c}}$ & $2828275 \pm 11.39^{\mathrm{a}, \mathrm{b}}$ \\
\hline $\begin{array}{l}\text { 3(2H)-furanone,-4-methoxy-2,5-dimethyl } \\
\text { (Mesifurane) }\end{array}$ & $6600808 \pm 19.54^{\mathrm{a}}$ & $13600772 \pm 0.64^{\mathrm{b}}$ & $1785937 \pm 14.44^{\mathrm{c}}$ & $6980647 \pm 14.51^{\mathrm{a}}$ \\
\hline 1-Octanol & $3137311 \pm 64.31^{\mathrm{a}}$ & $3695303 \pm 44.5^{\mathrm{a}}$ & $3592951 \pm 22.32^{\mathrm{a}}$ & $2814700 \pm 78.67^{\mathrm{a}}$ \\
\hline Linalool & $1151138 \pm 14.17^{\mathrm{a}}$ & $1764165 \pm 1.95^{\mathrm{a}}$ & ND & $5950901 \pm 21.24^{\mathrm{b}}$ \\
\hline Nonanal & $2497489 \pm 5.04^{\mathrm{a}}$ & $269386 \pm 2.13^{b}$ & $5288716 \pm 31.23^{c}$ & $1982454 \pm 7.25^{\mathrm{a}}$ \\
\hline \multicolumn{5}{|l|}{ 5-dihydroxy-6-methyl- } \\
\hline Ethanol,2-(2-butoxyethoxy)- & $607885 \pm 37.54^{\mathrm{a}}$ & $588287 \pm 0.95^{\mathrm{a}}$ & ND & ND \\
\hline L-alpha-terpineol & $45966 \pm 44.51^{\mathrm{a}}$ & $36107 \pm 12.30^{\mathrm{a}}$ & ND & ND \\
\hline Decanal & $1746636 \pm 28.76^{\mathrm{a}}$ & $3542893 \pm 1.38^{\mathrm{b}}$ & ND & ND \\
\hline Acetic acid, octyl ester & $534955 \pm 13.13^{\mathrm{a}}$ & $489652 \pm 5.20^{\mathrm{a}}$ & $3947927 \pm 14.10^{\mathrm{b}}$ & $1209814 \pm 31.67^{\mathrm{c}}$ \\
\hline 5-hydroxymethyl furfural & $366275 \pm 28.45^{\mathrm{a}}$ & $164398 \pm 10.76^{\mathrm{a}}$ & ND & ND \\
\hline $\begin{array}{l}\text { Propanoic acid, 2-methyl-, } \\
\text { 3--hydroxy-2,2,4-trimethylpentyl ester }\end{array}$ & $538535 \pm 5.02^{\mathrm{a}}$ & $313581 \pm 4.21^{\mathrm{a}}$ & $116387 \pm 1.64^{\mathrm{a}}$ & $341064 \pm 3.53^{\mathrm{a}}$ \\
\hline Butanoic acid, octyl ester & $1271621 \pm 25.06^{\mathrm{a}}$ & $4269375 \pm 2.36^{\mathrm{b}}$ & $3022711 \pm 11.48^{\mathrm{c}}$ & $1564762 \pm 47.49^{\mathrm{a}}$ \\
\hline Octyl 2-methylbutanoate & $1478588 \pm 11.66^{\mathrm{a}}$ & $2948636 \pm 2.50^{\mathrm{b}}$ & $2290430 \pm 23.87^{\mathrm{a}, \mathrm{c}}$ & $914771 \pm 50.36^{\mathrm{a,d}}$ \\
\hline Butanoic acid, 3-methyl, -octyl ester & $46941 \pm 16.93^{\mathrm{a}}$ & $33274 \pm 24.75^{\mathrm{a}}$ & $20332 \pm 13.04^{\mathrm{a}}$ & $246798 \pm 66.41^{\mathrm{b}}$ \\
\hline gamma-Decalactone & $10689 \pm 49.65^{\mathrm{a}}$ & $13484 \pm 33.24^{\mathrm{a}}$ & $1807659 \pm 84.48^{\mathrm{b}}$ & $314832 \pm 49.55^{\mathrm{c}}$ \\
\hline 1,6,10-dodecatrien-3 ol, 3,7-11 trimethyl ( $\mathrm{E}$ ) & $2856563 \pm 8.47^{\mathrm{a}}$ & $2329114 \pm 4.88^{\mathrm{a}}$ & $4910414 \pm 28.55^{\mathrm{a}}$ & $2689401 \pm 30.73^{\mathrm{a}}$ \\
\hline Hexanoic acid,octyl ester & $341559 \pm 30.29^{\mathrm{a}}$ & $843773 \pm 4.42^{\mathrm{b}}$ & $840087 \pm 56.96^{\mathrm{b}}$ & $211550 \pm 26.23^{\mathrm{a}}$ \\
\hline Butanoic acid,decyl ester & $31801 \pm 31.59^{\mathrm{a}}$ & $24403 \pm 17.63^{\mathrm{a}}$ & $267772 \pm 27.61^{\mathrm{b}}$ & $124987 \pm 34.45^{\mathrm{b}}$ \\
\hline$\gamma$-Dodecalactone & $23203 \pm 12.02^{\mathrm{a}}$ & $52063 \pm 7.59^{\mathrm{a}}$ & $414577 \pm 4.95^{\mathrm{b}}$ & $274804 \pm 40.15^{\mathrm{b}}$ \\
\hline $\begin{array}{l}\text { 7,9-Di-tert-butyl-oxaspiro(4,5)-deca-6, } \\
\text { 9-diene-2,8-dione }\end{array}$ & $162122 \pm 15.63^{\mathrm{a}}$ & $285203 \pm 10.17^{\mathrm{a}}$ & $117536 \pm 16.59^{\mathrm{a}}$ & $184061 \pm 8.47^{\mathrm{a}}$ \\
\hline
\end{tabular}

ND- not detected

Values followed by different letters denote significant difference $\mathrm{p}<0.05$ for each analyte in FD strawberry across the rows and those followed by same letters denote no significant difference.

Overall, there was a significant difference $(\mathrm{p}<0.05)$ for 10 volatile compounds when adding water or salt to whole FD strawberry for extraction (Tables 4). Some compounds that exhibited higher responses when extracted in water or salt solution included oxime, methoxy-phenyl, nonanal, acetic acid, octyl ester, gamma-decalactone, butanoic acid, decyl ester, and $\gamma$-dodecalactone. Adding salt to the whole strawberry seemed to generate greater peak responses only for oxime, methoxy phenyl, nonanal, acetic acid, octyl ester, gamma-decalactone, butanoic acid, decyl ester and $\gamma$-dodecalactone. Increasing the ionic strength brought the compounds to the volatile phase.

Twenty volatile compounds were able to be identified in the dry matrices in FD raspberry (Table 5). Three out of 20 analytes were not detected in the water and salt matrices. This is because ethanol,2-(hexyloxyl-), 4H-pyran-4-one, 2,3-dihydro-3,5-dihydroxy-6-methyl and 5-hydroxymethyl furfural are very soluble in water and are unable to go to the volatile phase for extraction. Of the 17 volatile compounds detected, the peak area response was slightly higher for the dry matrices ( 9 compounds) than for wet matrices ( 8 compounds). For FD raspberry, 
significant differences $(\mathrm{p}<0.05)$ in the peak areas existed for three of the volatile compounds when extractions for whole slices and powder were compared.

Table 5. Comparison of the effect of different matrices (whole, powder, whole and water, and whole and $20 \%$ sodium sulfate) on the SPME extraction efficiency of key volatile compounds in FD raspberry (Peak area $\pm \%$ RSD), $\mathrm{n}=3 . \quad 50 / 30 \mathrm{um} \mathrm{DVB} / \mathrm{CAR}-\mathrm{PDMS}$ fiber was used with $15 \mathrm{~min}$ for extraction time at $60^{\circ} \mathrm{C}$

\begin{tabular}{|c|c|c|c|c|}
\hline Compound & Whole & Powder & Whole in Water & $\begin{array}{l}\text { Whole in } 20 \% \\
\text { Sodium Sulfate }\end{array}$ \\
\hline Furfural & $\begin{array}{l}65959698 \\
16.60^{\mathrm{a}}\end{array}$ & $44461187 \pm 5.19^{\mathrm{a}}$ & $6965395 \pm 14.98^{\mathrm{a}}$ & $\begin{array}{l}20127299 \\
5.33^{\mathrm{a}}\end{array}$ \\
\hline Oxime,methoxy-phenyl & $1032884 \pm 4.59^{\mathrm{a}}$ & $1342056 \pm 8.94^{\mathrm{a}}$ & $7758191 \pm 3.41^{\mathrm{b}}$ & $5434575 \pm 9.69^{\mathrm{b}}$ \\
\hline 2-Furancarboxaldehyde, 5-methyl & $1650754 \pm 5.81^{\mathrm{a}}$ & $828639 \pm 6.08^{b}$ & $46203 \pm 19.13^{\mathrm{c}}$ & $600652 \pm 49.96^{\mathrm{d}}$ \\
\hline 2,4-Dihydroxy-2,5-dimethyl-3(2H)-furan-3one & $2334662 \pm 6.09^{\mathrm{a}}$ & $2591935 \pm 6.33^{\mathrm{a}}$ & $879927 \pm 14.75^{\mathrm{b}}$ & $\begin{array}{l}1157732 \\
21.79^{\mathrm{b}}\end{array}$ \\
\hline alpha-Phellandrene & $7171798 \pm 27.89^{\mathrm{a}}$ & $6225020 \pm 4.34^{\mathrm{a}, \mathrm{b}}$ & $8204421 \pm 16.42^{\mathrm{b}}$ & $431660 \pm 10.65^{\mathrm{c}}$ \\
\hline o-Cymene & $2464968 \pm 11.27^{\mathrm{a}}$ & $4864463 \pm 2.84^{\mathrm{a}}$ & $7626342 \pm 12.65^{\mathrm{b}}$ & $\begin{array}{l}3930305 \\
28.97^{\mathrm{a}}\end{array}$ \\
\hline D-Limonene & $\begin{array}{l}9189485 \quad \pm \\
13.72^{\mathrm{a}, \mathrm{d}}\end{array}$ & $\begin{array}{l}11473078 \quad \pm \\
4.61^{\mathrm{b}, \mathrm{c}, \mathrm{d}}\end{array}$ & $\begin{array}{l}10725574 \quad \pm \\
15.89^{c}\end{array}$ & $\begin{array}{l}8913517 \\
21.19^{d}\end{array}$ \\
\hline 2(3H)-Furanone dihydro, 3-hydroxy-4,4-dimethyl & $1219108 \pm 5.02^{\mathrm{a}}$ & $1103365 \pm 12.92^{\mathrm{a}}$ & $249529 \pm 65.90^{\mathrm{b}}$ & $290056 \pm 54.13^{\mathrm{b}}$ \\
\hline Linalool & $158366 \pm 5.70^{\mathrm{a}}$ & $169026 \pm 3.76^{\mathrm{a}}$ & $512848 \pm 11.27^{\mathrm{a}}$ & $\begin{array}{l}1559233 \\
47.94^{\mathrm{b}}\end{array}$ \\
\hline Nonanal & $2077823 \pm 8.50^{\mathrm{a}}$ & $1504867 \pm 6.13^{\mathrm{a}}$ & $3136660 \pm 3.96^{\mathrm{b}}$ & $\begin{array}{l}1874053 \\
13.55^{\mathrm{a}}\end{array}$ \\
\hline Ethanol,2-(hexyloxyl-) & $980123 \pm 6.98^{\mathrm{a}}$ & $370022 \pm 9.87^{\mathrm{a}}$ & ND & ND \\
\hline 4H-Pyran-4-one, 2,3-dihydro-3,5-dihydroxy-6-methyl & $2350148 \pm 6.21^{\mathrm{a}}$ & $2612961 \pm 0.87^{\mathrm{a}}$ & ND & ND \\
\hline 5-Hydroxymethyl furfural & $2964082 \pm 9.11^{\mathrm{a}}$ & $3163771 \pm 3.11^{\mathrm{a}}$ & ND & ND \\
\hline 2H-Pyran-2-one,tetrahydro-6-propyl & $1883719 \pm 27.35^{\mathrm{a}}$ & $1871741 \pm 3.67^{\mathrm{a}}$ & $357887 \pm 22.76^{\mathrm{b}}$ & $524200 \pm 42.84^{\mathrm{b}}$ \\
\hline $\begin{array}{l}\text { Propanoic acid, 2-methyl-, 3-hydroxy-2,2, } \\
\text { 4-trimethylpentyl ester }\end{array}$ & $292219 \pm 5.03^{\mathrm{a}}$ & $77190 \pm 8.46^{b}$ & $57715 \pm 22.35^{\mathrm{b}}$ & $192410 \pm 3.53^{\mathrm{c}}$ \\
\hline Caryophyllene & $1329522 \pm 58.38^{\mathrm{a}}$ & $999833 \pm 12.40^{\mathrm{a}}$ & $3749802 \pm 58.85^{\mathrm{a}}$ & $\begin{array}{l}3220045 \\
45.20^{\mathrm{a}}\end{array}$ \\
\hline$\alpha$-Ionone & $204055 \pm 20.31^{\mathrm{a}}$ & $146760 \pm 7.67^{\mathrm{a}}$ & $628675 \pm 15.69^{\mathrm{b}}$ & $528521 \pm 16.86^{\mathrm{b}}$ \\
\hline trans- $\beta$-Ionone & $7068983 \pm 31.89^{\mathrm{a}}$ & $4819243 \pm 8.67^{\mathrm{a}}$ & $15802506 \pm 4.63^{\mathrm{b}}$ & $\begin{array}{l}17129863 \\
5.27^{\mathrm{b}}\end{array}$ \\
\hline 2H-pyran-2-one,tetrahydro-6-pentyl & $2177198 \pm 31.20^{\mathrm{a}}$ & $1597128 \pm 9.95^{\mathrm{a}}$ & $722914 \pm 44.08^{b}$ & $\begin{array}{l}1347073 \\
30.59^{\mathrm{a}}\end{array}$ \\
\hline $\begin{array}{l}\text { 7,9-Di-tert-butyl-oxaspiro(4,5)-deca-6,9-diene-2,8-dio } \\
\text { ne }\end{array}$ & $128819 \pm 5.07^{\mathrm{a}}$ & $109711 \pm 20.53^{\mathrm{a}}$ & $71121 \pm 12.73^{\mathrm{a}}$ & $78274 \pm 31.93^{\mathrm{a}}$ \\
\hline
\end{tabular}

ND- not detected

Values followed by different letters denote significant difference $\mathrm{p}<0.05$ for each analyte in FD raspberry across the rows and those followed by same letters denote no significant difference.

Significant difference $(\mathrm{p}<0.05)$ was determined in eight volatile compounds when adding water or salt to whole slices of FD raspberry for extraction. Volatile compounds that demonstrated higher responses when extracted in water or salt solution included o-cymene, linalool, nonanal, $\alpha$-ionone, and trans- $\beta$-ionone. The ionic strength of the sample usually increases with the addition of salt allowing the compounds to go to the volatile phase if they are soluble in water. However, this did not make much of a difference in this experiment.

\subsection{Quantitation of Select Volatiles}

This HS-SPME-GC-MS method was used to quantify select key aroma compounds of interest for FD strawberry and raspberry. These included furfural, mesifurane, and gamma-decalactone for FD strawberry and furfural, alpha-ionone and beta-ionone. In general, excellent correlation coefficients were obtained for the selected aroma compound standards $\left(\mathrm{R}^{2}>0.99\right)$ with the 50/30 $\mu \mathrm{m}$ DVB/CAR-PDMS SPME fiber. 
Mesifurane, the major odor-active compound, found in fresh strawberry was determined to contain the highest concentration $(93.25 \pm 29.5 \mu \mathrm{g} / \mathrm{g})$ in the FD strawberry compared to furfural $(8.27 \pm 1.06 \mu \mathrm{g} / \mathrm{g})$ and gamma-decalactone $(9.48 \pm 0.31 \mu \mathrm{g} / \mathrm{g})$. Unlike the FD strawberry quantity determined for furfural, FD raspberry had a much greater amount $(32.20 \pm 4.27 \mu \mathrm{g} / \mathrm{g})$. FD raspberry contained a lower content of alpha-ionone $(0.20 \pm$ $0.02 \mu \mathrm{g} / \mathrm{g})$ and beta-ionone $(0.30 \pm 0.04 \mu \mathrm{g} / \mathrm{g})$.

\section{Conclusion}

This study was able to identify several volatile compounds and quantitate select, important ones in FD strawberry and raspberry that are similar to those of the fresh fruits with HS-SPME-GC-MS. The most important aroma compounds found in FD strawberry were mesifurane followed by furfural, while furfural was the major compound identified in FD raspberry followed by $\alpha$-ionone and $\beta$-ionone. In fresh strawberry, mesifurane and furaneol are the major aroma compounds detected followed by esters (Hadi et al., 2013; Jetti et al., 2007; Jouquand \& Chandler, 2008; Forney, 2001). The key aroma compounds contained in fresh raspberry were raspberry ketone, $\alpha$-ionone and $\beta$-ionone (Hadi et al., 2013; Du \& Qian, 2010; Aprea et al, 2015). Concentrations of volatile compounds in strawberry and raspberry fruits can vary depending on cultivar, fruit ripening stage, environmental conditions, different extraction and analysis techniques. This investigation is important for determining the quality of freeze-dried ingredients of strawberry and raspberry alone or when added to other food products, such as cereals, nutritional bars, or confectionary items.

\section{References}

Aisala, H., Sola, J., Hopia, A., Linderborg, K. M., \& Sandell, M. (2019). Odor-contributing volatile compounds of wild edible Nordic mushrooms analyzed with HS-SPME-GC-MS and HS-SPME-GC-O/FID. Food Chemistry, 283, 566-578. https://doi.org/10.1016/j.foodchem.2019.01.053

Aprea, E., Biasiolli, F., \& Gasperi, F. (2015). Volatile compounds of raspberry fruit: from analytical methods to biological role and sensory impact. Molecules, 20, 2445-2474. https://doi.org/10.3390/molecules20022445

Aprea, E., Biasioli, F., Carlin, S., Endrizzi, I., \& Gasperi, F. (2009). Investigation of volatile compounds in two raspberry cultivars by two headspace techniques: solid-phase microextraction/gas chromatography-mass spectrometry (SPME/GC-MS) and proton-transfer reaction-mass spectrometry (PTR-MS). Journal of Agricultural and Food Chemistry, 57, 4011-4018. https://doi.org/10.1021/jf803998c

Ciurzyríska, A., \& Lenart, A. (2011). Freeze-drying- Application in food processing and biotechnology- A review. Polish Journal of Food and Nutrition Sciences, 61, 165-171. https://doi.org/10.2478/v10222-011-0017-5

Du, X., \& Qian, M. (2010). Flavor chemistry of small fruits: blackberry, raspberry, and blueberry. In X. Du, \&, M. Qian (Eds.), Flavor and health benefits of small fruits (pp. 27-43). ACS Symposium Series, American Chemical Society, Washington, D.C. https://doi.org/10.1021/bk-2010-1035.ch003

Du, X., Plotto, A., Baldwin, E., \& Rouseff, R. (2011). Evaluation of volatiles from two subtropical strawberry cultivars using GC-Olfactometry, GC-MS odor activity values, and sensory analysis. Journal of Agricultural and Food Chemistry, 59, 12569-12577. https://doi.org/10.1021/jf2030924

Ducki, S., Miralles-Garcia, J., Zumbé, A., Tornero, A., \& Storey, D. M. (2008). Evaluation of solid-phase micro-extraction coupled to gas chromatography-mass spectrometry for the headspace analysis of volatile compounds in cocoa products. Talanta, 74, 1166-1174. https://doi.org/10.1016/j.talanta.2007.08.034

Forney, C. F. (2001). Horticultural and other factors affecting aroma volatile composition of small fruit. Horttechnology, 11, 529-538. https://doi.org/10.21273/Horttech.11.4.529

Hadi, M. A., Zhang, F.-J., Wu, F.-F., Zhou, C.-H., \& Tao, J. (2013). Advances in fruit aroma volatile research. Molecules, 18, 8200-8229. https://doi.org/10.3390/molecules18078200

Jetti, R. R., Yang, E., Kurnianta, A., Finn, C., \& Qian, M. C. (2007). Quantification of selected aroma-active compounds in strawberries by headspace solid-phase microextraction gas chromatography and correlation with sensory descriptive analysis. Journal of Food Science, 72, S487-S496. https://doi.org/10.1111/j.1750-3841.2007.00445.x

Jouquand, C., \& Chandler, C. (2008). A sensory and chemical analysis of fresh strawberries over harvest dates and seasons reveals factors that affect eating quality. Journal of the American Society of Horticulturae Science, 133, 859-867. https://doi.org/10.21273/JASHS.133.6.859

Sanz, C., Belaj, A., Sánchez-Ortiz, A., \& Pérez, A. (2018). Natural variation of volatile compounds in virgin olive oil analyzed by HS-SPME/GC-MS-FID. Separations, 5, 24. 
https://doi.org/10.3390/separations5020024

Vas, G., \& Vékey, K. (2004). Solid-phase microextraction: a powerful sample preparation tool prior to mass spectrometric analysis. Journal of Mass Spectrometry, 39, 233-254. https://doi.org/10.1002/jms.606

Weerawatanakorn, M., Wu, J.-C., Pan, M.-H., \& Ho, C.-T. (2015). Reactivity and stability of selected flavor compounds. Journal of Food Drug Analysis, 23, 176-190. https://doi.org/10.1016/j.jfda.2015.02.001

\section{Copyrights}

Copyright for this article is retained by the author(s), with first publication rights granted to the journal.

This is an open-access article distributed under the terms and conditions of the Creative Commons Attribution license (http://creativecommons.org/licenses/by/4.0/). 